\section{Research priorities and opportunities within the forestry and agroforestry sectors in} Albania

\author{
Pisanelli $A^{(1)}$, Bregasi $M^{(2)}$, Jupe $A^{(3)}$, Toromani $E^{(3)}$ \\ The present paper is the report of a study travel carried out in Albania in May \\ 2009, which was financed by a Short Term Mobility Program of the Italian Na- \\ tional Council of Research (CNR). During the stay, a scientific collaboration was \\ established between the Institute of Agro-environmental and Forest Biology - \\ CNR and the Agricultural University of Tirana and several formal and informal \\ meetings and interviews were arranged with different stakeholders involved in \\ forestry and agroforestry sectors. Bibliographic materials were also collected \\ and analysed. The specific aim of the paper is to highlight some research \\ themes and priorities that could be implemented through specific projects and \\ programmes.
}

Keywords: International cooperation, Rural development, Non timber forest products, Biomass for energy, Plantation forestry

\section{Introduction}

The Short Term mobility Programme, financed by Italian National Research Council (CNR), was carried out in Albania in May 2009 , with the overall aim to establish and implement a scientific collaboration between the Institute of Agro-environmental and Forest Biology (IBAF, Porano, TR - Italy) and the Agricultural University of Tirana (AUT).

During the stay, several meetings were organised and formal and informal interviews were carried out with many stakeholders (policy makers; Albanian Government representatives, such as the Ministry of Agriculture, Food and Consumer Protection; the Ministry of the Environment, the Forest and Water Administration; researchers and scientists with a wide range of competences in the agricultural and forestry sciences; actors responsible for administrating local communities, called Komuna;

(1) Istituto di Biologia Agroambientale e Forestale, CNR, Porano (TR - Italy); (2) Faculty of Economy and Agribusiness, Agricultural University of Tirana (Albania); (3) Faculty of Forestry Science, Agricultural University of Tirana (Albania)

\section{(a), Andrea Pisanelli}

(andrea.pisanelli@ibaf.cnr.it)

Received: Nov 16, 2009 - Accepted: May 02, 2010

Citation: Pisanelli A, Bregasi M, Jupe A, Toromani E, 2010. Research priorities and opportunities within the forestry and agroforestry sectors in Albania. iForest 3: 113-117 [online: 2010-09-27] URL: http://www.sisef.it/iforest/show.php? id $=534$ small wood industries) in order to assess the major needs and constraints and to evaluate the potentialities of the agricultural sector in Albania. The study's principal focus was on forestry and agroforestry systems. Available bibliographic materials (scientific articles, conference proceedings, statistical data) were collected and two field trips were made in sample rural and forestry areas (in the north-west, close to Shkodra, and in the east, close to Librazhd)

1.description of forestry and agroforestry systems in Albania, focusing on the potentialities of Non-Timber Forest Products (NTFPs) and renewable energy sectors;

2. highlight of the impact of the political and institutional changes affecting the agricultural sector since the end of communist period;

3. identification of research topics and priorities that could be implemented through appropriate programmes and development strategies.

\section{Agroforestry systems and non-} timber forest products economy in Albania

According to official statistics (Ministry of Agriculture, Food and Consumer Protection 2008), Albania covers a territory of almost 2.9 million ha, with a total population of about 3.6 million inhabitants and a density of 125 inhabitants $\mathrm{km}^{-2}$. Agricultural lands cover about $24 \%$ of the total area, forests and pasture more than half of the whole territory (Tab. 1).

Since 1990 many significant changes (in primis market reform and institutional changes) have affected the Albanian eco-
The objectives of this paper are: nomy and social structure. Before its transition to a market economy, in the early ' $90 \mathrm{~s}$, Albanian industry contributed over $50 \%$ to the national Gross Domestic Product (GDP). Industrial production decreased sharply after the end of the state-controlled economy and in 2006 it only amounted to about $11 \%$ to the national GDP (INSTAT 2008).

Since the beginning of the new century, Albania has been considered an institutionally stable State, thanks to the reform process that aligned the country to a Western Economy; in fact since the beginning of 2000 , the private sector has controlled about $80 \%$ of the country's economy.

Although Albania continues to witness a significant reduction in poverty $(12.4 \%$ of the population was considered poor in 2008 compared with $18.5 \%$ in 2005 and $25.4 \%$ in 2002), it remains one of the poorest countries in Europe (United Nation Development Programme 2009). Agriculture contributes to about $20 \%$ of GDP and about $60 \%$ of the labour force is employed in the agricultural sector (Central Intelligent Agency 2008). Italy is Albania's main trading partner: about $26 \%$ of imports come from Italy and about $68 \%$ of country's exports go to Italy (ICE 2008).

Rural areas and forests are rich in natural resources, thereby creating a diverse landscape; moreover, the presence of a strong culture and traditions guarantees the conservation of significant biodiversity "hotspots" (Regional Environmental Centre 2000). The Mediterranean climate is extremely favourable for rich agrarian biodiversity, even if wide tracks of arable lands are subjected to excessive human pressure. The warm climate, together with the traditional knowledge and competency in agricultural practises on the part of rural communities, allow the cultivation a wide variety of crops and of fruit trees. Traditional Mediterranean agroforestry systems are widespread in the rural landscape where it is common to find multiproductive systems comprising trees, crops (both cereals and fodders grown for animals) and animals (sheep, goats and cows) on small plots close to the farmhouse. Olive trees, and fruit trees together with vineyards are the most common woody components of these agroforestry systems. The extensive traditional knowledge of rural communities

Tab. 1 - Overview of Albanian land use systems.

\begin{tabular}{lrr}
\hline \multicolumn{1}{c}{ Description } & \multicolumn{1}{c}{ ha } & \% \\
\hline Agricultural area & 697000 & 24 \\
Forest and pasture area & 1464000 & 51 \\
Other area & 713000 & 25 \\
Total territorial area & 2874000 & 100 \\
\hline
\end{tabular}




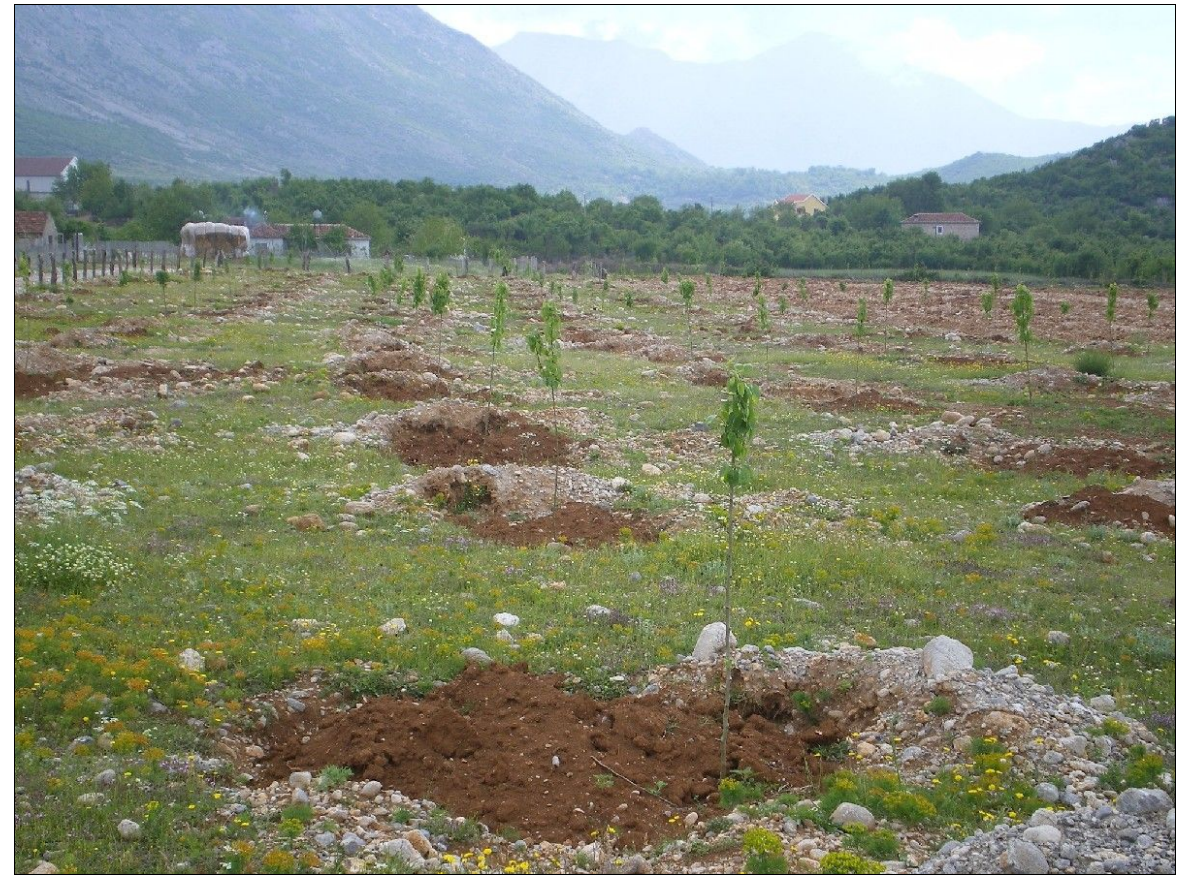

Fig. 1 - Tree plantation with fruit trees close to Shkodra. Tree planting for fruit production is traditional in Albania; new plantations are expanding, walnut and cherry being the most interesting species (photo: A. Pisanelli).

should be valued because land and natural resource management based on the knowledge of indigenous people, allows for a mosaic of landscape, in which several biological components are integrated to provide a wide range of products (IUFRO 2007).

Following the events and circumstances occurred since the early ' 90 s, environmental

Tab. 2 - Most important medicinal and aromatic plants exported from Albania in 2001.

\begin{tabular}{|c|c|c|}
\hline Species & $\begin{array}{l}\text { Quantity } \\
\text { (tonnes) }\end{array}$ & $\begin{array}{l}\text { Plant part } \\
\text { used }\end{array}$ \\
\hline Salvia spp. & 1000 & Leaves \\
\hline Origanum vulgare & 800 & Herb \\
\hline Satureja montana & 500 & Herb \\
\hline Thymus vulgaris & 440 & Herb \\
\hline $\begin{array}{l}\text { Hypericum } \\
\text { perforatum }\end{array}$ & 424 & Herb \\
\hline Rubus idaeus & 380 & $\begin{array}{l}\text { Leaves/ } \\
\text { fruit }\end{array}$ \\
\hline Melissa officinalis & 350 & Leaves \\
\hline $\begin{array}{l}\text { Juniperus } \\
\text { oxycedrus }\end{array}$ & 285 & Berries \\
\hline $\begin{array}{l}\text { Crataegus } \\
\text { monogyna }\end{array}$ & 240 & $\begin{array}{c}\text { Leaves/ } \\
\text { berries }\end{array}$ \\
\hline Rosa canina & 200 & Fruits \\
\hline Trifuluim spp. & 152 & Flowers \\
\hline Primula veris & 105 & Flowers \\
\hline Orchis spp. & 100 & Tubers \\
\hline $\begin{array}{l}\text { Juniperus } \\
\text { communis }\end{array}$ & 85 & Berries \\
\hline Sideritis raeseri & 75 & Herb \\
\hline
\end{tabular}

products for its livelihood.

Although the rural sector is not efficient in its practices (due to lack of rural infrastructure, low incomes, poor credit, low investment and small farm size) the agricultural sector is regardless playing the most important role in the development of Albanian economy (Jupe et al. 2009). Most of the rural income $(57 \%$ of the total agricultural product values) derives from livestock activity with sheep and goat grazing being the most important. Arable crops and fruits represent $29 \%$ and $14 \%$ respectively of farmers' incomes (Ministry of Agriculture, Food and Consumer Protection 2007). Tree planting for fruit production (walnut, cherry, maple being the most common species) is expanding in several areas of the country (Fig. 1).

The forestry industry is based on smallscale production and most of the products are exported, with only a limited amount (about 20\%) sold domestically. However, local demand is growing due to ever increasing requests for housing and furniture.

Albania, like other Balkan countries, has a great tradition in Non Timber Forest Products (NTFPs) that have always been an important economic resource, above all in rural and mountain areas. However, harvesting and marketing of goods are poorly organised nowadays. Before 1990 Albania was one of the main producers of NTFPs in Europe, especially medicinal and aromatic plants. While under state control, the entire chain of organisation was "excellently run" (Ina Pagria, personal communication), presently several small private enterprises have replaced the state-controlled trade and the harvest is an important source of revenue in rural areas where the poverty is prevalent. According to Kullaj (2009) for many rural communities living in Albania the collection of medicinal and aromatic plants constitutes a greater source of income than from any other agricultural products or from livestock management. Almost all medicinal and aromatic plants are collected wild $90 \%$ of the plants are exported, with the USA, Germany, Italy and France being the main markets). Usually people harvest and dry the plants; then transport them to the wholesalers. Some of the problems that Albania are facing now under the new system are: premature harvesting before the plants are totally matured, excessive harvesting, improper harvesting techniques that damage the plants, poor storage techniques and low prices (Kathe et al. 2003, Ricciardi 2003).

The most frequently collected medicinal and aromatic species in 2001 are listed in Tab. 2. In the same year, Albania sold about 10000 tonnes of raw material of dried medicinal and aromatic plants in the international market. The harvesters usually belong to under privileged social groups (children, women and older people) living in poor rural 
areas (Kathe et al. 2003) and it is the task of the Forest Inspectorate of the Forest Service Directorate to control and monitor the harvest. It is estimated that in Albania about 76000 people are employed in the gathering and processing of NTFPs (Kullaj 2009), accounting for $13 \%$ of total employment in agricultural sector. Although over $90 \%$ of medicinal and aromatic plants are collected in the wild, trade companies are requesting to intensify domestication and cultivation (Fig. 2). Nevertheless, a comprehensive approach to the cultivation of medicinal plants in farmlands has yet to be developed (Kathe et al. 2003).

\section{Forestry resources and the potential of the Albanian forest sector in the production of renewable energy}

Albania is one of the few European countries where forests have declined in recent decades: according to MCPFE (2007) the country recorded the highest reduction of forest area and growing stock during the period 2000-2005; Earth trends (2003) estimated a $7 \%$ reduction of forest area during the period 1990-2000.

The National Forestry Inventory (Agrotec Consortium 2004) estimated that forest area per capita is about 0.4 ha. According to the Inventory, $41 \%$ of forests are managed as coppice, $30 \%$ as high forests and $29 \%$ as shrubs (Tab. 3). Timber production is considered the most important function in $78 \%$ of the forests, while protection and grazing are the main functions in $48 \%$ and $40 \%$ of the total forest area, respectively.

High forests have a major role in the supply of timber; coppice forests provide a major source of fuelwood. Most of the coppice forests are in poor condition, mainly due to illegal logging; thus the adoption of appropriate management plans is urgently required for guaranteeing sustainability in the long term. Shrub areas are the most favourable environments for livestock and harvesting of NFTPs.

Beech and oaks are the most important broad-leaved species; black pine and firs are the most important species among the conifers. Forest resources in Albania have been overexploited since the '50s and, nowadays, large tracks of forests are in a juvenile state. The massive use of oak together with deforestation for agricultural purposes has caused a huge reduction of biodiversity and severe soil erosion (Dida 2003) and, the resulting shortage leaves beech as one of the few raw materials that can be presently utilised by the sawmill industries.

In terms of volume availability, most of the timber $(80 \%)$ is concentrated in high forests and only about $20 \%$ in coppice forests. Within the high forest typologies, the available timber volume is concentrated in 3

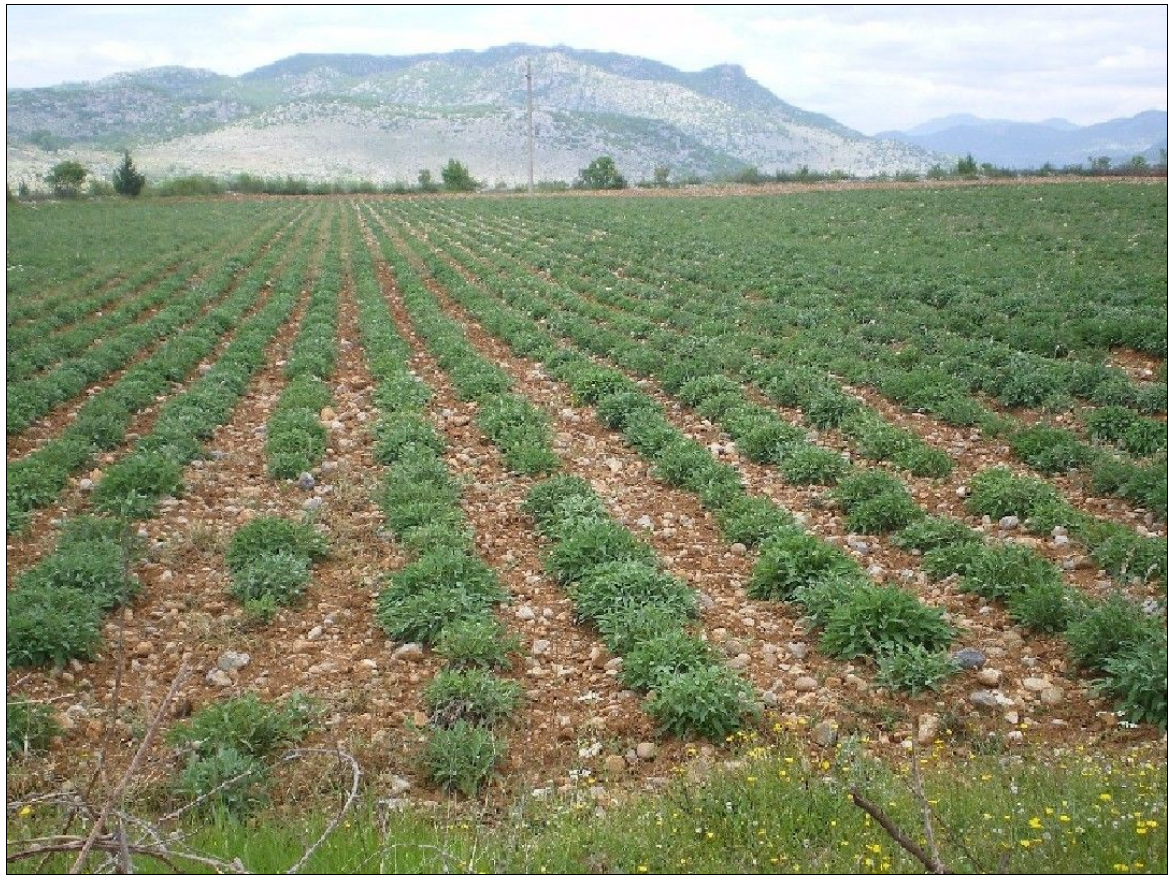

Fig. 2 - Field with Salvia spp. close to Shkodra. Medicinal and aromatic plants represent one of the main NTFPs in Albania and the expansion of domestic cultivation is encouraged (photo: A. Pisanelli).

main species: beech having the largest percentage of volume, followed by black pine and firs (Tab. 4). In coppice forests most of the volume is concentrated in oak populations $(45 \%)$. Presently forests are under the control of Komuna, who are responsible for the management and monitoring of forest resources. From the interviews carried out there emerged a lack of expertise and com-

Tab. 3 - Area and timber volume of different forest types (adapted from Agrotec Consortium 2004). Forests are often in poor condition because they have been over utilised since the '50s.

\begin{tabular}{lrrrcr}
\hline $\begin{array}{c}\text { Forest } \\
\text { management }\end{array}$ & Area (ha) & \% & V/ha $\left(\mathbf{m}^{\mathbf{3}}\right)$ & $\begin{array}{c}\text { Total volume } \\
\left(\mathbf{1 0 0 0} \mathbf{~ m}^{\mathbf{3}}\right)\end{array}$ & $\%$ \\
\hline High forest & 448922 & 30 & 131.68 & 59112 & 80.4 \\
Coppice & 623799 & 41 & 22.82 & 14235 & 19.4 \\
Shrubs & 429440 & 29 & 0.46 & 198 & 0.2 \\
Total & 1502161 & 100 & 154.96 & 73545 & 100 \\
\hline
\end{tabular}

Tab. 4 - Estimated volume for different tree species components of high forests.

\begin{tabular}{lccc}
\hline $\begin{array}{c}\text { Forest } \\
\text { tree species }\end{array}$ & $\begin{array}{c}\text { V/ha } \\
\left(\mathbf{m}^{\mathbf{3}}\right)\end{array}$ & $\begin{array}{c}\text { Total volume } \\
\left(\mathbf{1 0 0 0} \mathbf{~ m}^{\mathbf{3}} \mathbf{)}\right.\end{array}$ & \% \\
\hline Pinus nigra & 19.69 & 8841 & 15 \\
Abies spp. & 8.93 & 4010 & 6.8 \\
Pinus spp. & 1.8 & 810 & 1.4 \\
Other coniferous trees & 4.57 & 2050 & 3.5 \\
Fagus sylvatica & 81.46 & 36571 & 61.9 \\
Quercus spp. & 5.64 & 2530 & 4.3 \\
Other broad leaved trees & 8.6 & 3860 & 6.5 \\
Shrubs & 0.98 & 440 & 0.7 \\
Total & 131.68 & 59112 & 100 \\
\hline
\end{tabular}

petence at the local level regarding sustainable forestry management skills. Given this, it would be advisable to implement training courses and capacity building in order to improve the skills and know-how of personnel of local administrations.

Agrotec Consortium (2004) recommended starting afforestation programs, through international cooperation, with the aim of in- 
Tab. 5 - Percentage of households using fuelwood as main energy sources in different areas.

\begin{tabular}{lccc}
\hline & \multicolumn{3}{c}{$\begin{array}{c}\text { Percentage of households } \\
\text { according to the altitude }\end{array}$} \\
\cline { 2 - 4 } Type & $\mathbf{0 - 4 0 0}$ & $\mathbf{4 0 1 - 8 0 0}$ & $\mathbf{8 0 1 - 1 6 0 0}$ \\
& $\mathbf{m}$ & $\mathbf{m}$ & $\mathbf{m}$ \\
\hline Forest area & 82 & 92 & 98 \\
Rural area & 62 & 89 & 98 \\
Urban area & 29 & 65 & 73 \\
\hline
\end{tabular}

Tab. 6 - Different sources of fuelwood within the rural and mountain households in Albania.

\begin{tabular}{lc}
\hline \multicolumn{1}{c}{ Sources } & Percentage \\
\hline $\begin{array}{l}\text { Directly from the nearby forests } \\
\text { Bought from a unidentified }\end{array}$ & 60 \\
seller & 22 \\
Have not incurred the need & 10.2 \\
Bought from licensed seller & 5.4 \\
Other sources & 2 \\
Directly from the forests & 0.4 \\
located in other villages & \\
Total & 100 \\
\hline
\end{tabular}

creasing timber supply, mitigate climate changes and improve socio-economic conditions of rural communities.

The production of biomass for energy should be one of the main aims of new plantations. During the last 15 years, Albania entered the free market economy, and it has come a growing need for energy. Albania has two main sources of energy: the first is hydroelectric power from rivers and the second is oil/gas. Hydroelectric power accounts for a significant proportion of $\mathrm{Al}$ bania's domestic energy production, estimated as $95.3 \%$. Nevertheless the production is not sufficient to fulfil energy requirements and, consequently, it is necessary to import energy in order to satisfy the remaining demand. During the last decades the Albania's energy production has not changed, while demand has increased considerably: in 2004 for example, Albania met only 55\% of its energy demands (INSTAT 2005).

Therefore, the country is faced with the challenge of expanding its energy production from both existing and alternative sources. In this context, the forest sector in Albania could play a significant role in providing renewable energy in order to fulfil its domestic demands. At present, wood is still the primary and main heating source in rural and mountain communities (Tab. 5), where population is characterised by a low income level. Most of the local people get firewood directly from the forests that grow around the villages for free (Tab. 6).
According to INSTAT (2005), the sustainable annual wood harvesting possibility is about $1152000 \mathrm{~m}^{3}$. Considering the number of families living in rural and mountain areas (400 000) with an annual average wood requirement of $5 \mathrm{~m}^{3}$, it is estimated that fuelwood consumption in rural and mountain soars to about $2000000 \mathrm{~m}^{3}$. The gap between the harvesting possibility and fuelwood consumption is clearly the result of illegal cutting.

Artificial tree plantations with species of short cultural cycle (short rotation forestry) such as poplar, willow, black locust, and eucalypts would contribute to reduce the gap between demand and supply.

\section{Conclusions}

In Albania agriculture and forestry seem to be the most relevant sectors through which poverty and migration could be reduced as they represent the main sources of income in the wide rural and mountain communities of the country. Albania is a country with great potentialities thanks to its rich biodiversity and value landscape. Because of this, tourism is increasing and, if valuable product chains were organised, local agroforestry products would stimulate employment in rural communities and contribute to reduce poverty.

According to the study carried out during the short mobility stay, several research priorities and development strategies would need to be urgently implemented.

1. implementation of afforestation programmes in degraded lands utilising the most suitable forest tree species with the aim of reducing soil degradation and improving the landscape;

2. adoption of forest management plans in mountain areas in order to increase the availability and the diversity of raw materials for timber industries, the fuelwood production and reduce the illegal logging;

3. development and organisation of NTFPs' chains, especially for medicinal and aromatic plants, promoting domestication and cultivation of the most important essences. This would reduce the human impact in the wild, increase product quality and improve the livelihood of people in areas of low economic income;

4. expansion of tree planting in existing abandoned lands with the aim of producing fruit, timber (i.e., using double purpose species like walnut and cherry) and biomass (i.e., short rotation forestry model);

5. support capacity building at the local level in sustainable development through the training of local communities and local administrators in environment protection skills;

6. education programs for local populations which promote awareness and respect of the environment and the sustainable use of natural resources;

7. coordination and collaboration among stakeholders involved in the management and utilisation of natural resources.

Finally, effective actions should be taken for the adoption of the REDD process (Reducing Emissions from Deforestation and Forest Degradation). This REDD process is a set of steps designed to use market/financial incentives to reduce the emissions of greenhouse gases from deforestation and forest degradation. The process would bring with it other benefits such as biodiversity conservation and alleviation of poverty (UN/REDD 2009).

\section{Acknowledgements}

The research was supported by Consiglio Nazionale delle Ricerche, Short Mobility Programme, 2009.

\section{References}

Agrotec Consortium (2004). Albanian National Forestry Inventory. Final report. Tirana, Albania, pp. 140 .

Baumann P (2002). Improving access to natural resources for rural people. A critical analysis of central concepts and emerging trends from a sustainable livelihoods perspective. FAO, Livelihood Support Programme, pp. 47.

Central Intelligent Agency (2008). The world factbook. [online] URL: https:/www.cia.gov/library/ publications/the-world-factbook/index.html

Dida M (2003). State of forest tree genetic resources in Albania. Forest Genetic Resources Working Papers, Working Paper FGR/62E, Forest Resources Development Service, Forest Resources Division, FAO, Rome. [online] URL: http://www.fao.org/docrep/007/j2108e/j2108e00. htm

Earth trends (2003). Forests, grasslands and drylands. [online] URL: http://www.earthtrends. wri.org/

ICE (2008). Rapporto paesi congiunti ambasciate/ uffici Ice estero. Aggiornamento al II semestre 2008. Istituto Nazionale per il Commercio Estero, Ministero degli Affari Esteri, Rome, Italy, pp. 16. [online] URL: http://www.esteri.it/rapporti/pdf/albania.pdf

INSTAT (2005). Vjetari statistikor 1993-2003. pp 51. [online] URL: http://www.instat.gov.al

INSTAT (2008). Albania in figures. pp. 25 [online] URL: http://www.instat.gov.al

IUFRO (2007). Guidelines for the implementation of social and cultural values in sustainable forest management. International Union of Forest research Organization (IUFRO), Research Group 6.07.00 "Forest and Woodland History", Occasional paper n. 19, pp. 28. [online] URL: http://www.ukeconet.co.uk/images/stories/news/ iufropaper.pdf

Jupe A, Murrja A, Sulçe S, Shehu D (2009). Problems and alternatives of development of subsistence farms of benefit to reduction of rural poverty. In: Proceedings of the conference "Farm efficiency and the vertical integration of actors as 
factors contributing to increase of competitiveness. Role of private and public actors". Tirana (Albania) 2009, pp. 70.

Kathe W, Honnef S, Heym A (2003). Medicinal and aromatic plants in Albania, Bosnia-Herzegovina, Bulgaria, Croatia and Romania. German Federal Agency for Nature Conservation (BfN). Skripten 91, Bonn and Vilm, Germany, pp. 201. [online] URL: http://www2.bfn.de/ fileadmin/MDB/documents/skript91.pdf

Kullaj E (2009). Socio-economic value and fire risk threatening medicinal and aromatic plants of South Albania. In: Proceedings of the conference "Fires: a risk that has no frontiers. Fire risk management in forest and pasture ecosystems of Albania-Greece cross border Regions". Tirana (Albania), May 2009, pp. 267.

MCPFE (2007). State of Europe's forests 2007. Jointly prepared by the MCPFE Liaison Unit Warsaw, UNECE and FAO. [online] URL: http://forestportal.efi.int/view.php?id=1895\&c=
E1

Ministry of Agriculture, Food and Consumer Protection (2008). Statistical Yearbook 2007. Agriculture, Livestock, Agro-industry. pp. 128. Tirana, April 2008.

Osservatorio Balcani e Caucaso (2003). Albania: fuga verso le città. [online] URL: http:/www. osservatoriobalcani.org/article/articleview/1795/ $1 / 41 /$

Regional Environmental Centre (2000). Strategic environmental analysis of Albania, Bosnia \& Herzegovina, Kosovo and Macedonia. Final Report, pp. 37. Study prepared for Sida by Scandiaconsult Natura $\mathrm{AB}$ and The Regional Environmental Centre for Central and Eastern Europe. [online] URL: http://www.rec.org

Ricciardi L (2003). La tutela ambientale Albanese non può prescindere dalla salvaguardia e valorizzazione delle risorse genetiche di specie agrarie e officinali. Proceedings of the: "Iniziative scientifiche dell'Ambasciata d'Italia, anno
2003. Sviluppo sostenibile per l'Albania". In collaboration with the Ministry of Education and Sciences of the Albanian Republic, Tirana, Albania. [CD rom].

UN/REDD (2009). The United Nations collaborative programme on reducing emissions from deforestation and forest degradation in developing countries. United Nation REDD programme. [online] URL: http://www.un-redd.org/

UNDP/GEF (1999). Country strategy. Tirana (A1bania). United Nation Development Programme Global Environment Facility, April 1999. [online] URL: http://www.undp.org.al/index.php? page=about_us/undp_albania

United Nation Development Programme (2009). Albania continues to witness significant poverty reduction. [online] URL: http://www.undp.org.al/ index.php? page $=$ detail $\&$ id $=123$ 